\title{
Pandemic Emotions: The Extent, Correlates, and Mental Health Consequences of Personal and Altruistic Fear of COVID-19
}

\author{
Melissa M. Sloan \\ University of South Florida \\ Murat Haner \\ University of South Florida \\ Amanda Graham \\ Georgia Southern University \\ Francis T. Cullen \\ University of Cincinnati \\ Justin T. Pickett \\ University at Albany \\ Cheryl Lero Jonson \\ Xavier University
}

Direct correspondence to Melissa Sloan, University of South Florida, Department of Sociology, 4202 E. Fowler Avenue, CPR 107, Tampa, FL 33620 (e-mail: melissasloan@usf.edu)

\section{Recommended Citation:}

Sloan, M. M., Haner, M., Graham, A., Cullen, F. T., Pickett, J. T., \& Jonson, C. L. (2020).

Pandemic Emotions: The Extent, Correlates, and Mental Health Consequences of Personal and Altruistic Fear of COVID-19. Working Paper, University of South Florida. 


\title{
Pandemic Emotions: The Extent, Correlates, and Mental Health Consequences of Personal and Altruistic Fear of COVID-19
}

\begin{abstract}
COVID-19 has had unprecedented effects on populations around the world. Given the political and moral context of the pandemic and the nation's response to it, this study sought to assess the extent of American's personal fear about the virus as well as their fear for others (altruistic fear), identify potential predictors of these fears, and examine the mental health impact of heightened COVID-19 fears. Overall, a majority of respondents worried about various aspects of the virus, from being exposed to dying and reported often worrying about others, including family, the elderly, and healthcare professionals. Building on the fear of crime literature, we find that certain individuals, including those who believe they are at a high risk of dying from the virus, those who closely follow news coverage of the pandemic, and those with strong moral foundations, are likely to experience elevated fear and, possibly, its consequences.
\end{abstract}

Keywords: COVID-19, personal fear, altruistic fear, psychological distress, Moral Foundations Theory, faith in Trump 
Originating first as an unexplained case of pneumonia in the Chinese city of Wuhan, the novel coronavirus (COVID-19) quickly became a "public health emergency of international concern" which has led to fear, worry, and anxiety among individuals around the world (Ahorsu et al., 2020; Garfin et al., 2020; Kurl \& Korzinski, 2020). As of this writing, more than 3.3 million people have contracted COVID-19 globally, and 235,000 of them have died. The number of people in the United States known to have been infected by the virus has surpassed one million with more than 64,000 deaths, and infection rates continue to increase daily (Johns Hopkins, 2020).

The community spread and high mortality rates of COVID-19 have already dramatically altered many aspects of our daily routines, including how we live, interact with each other, and conduct businesses. In order to slow the spread of the virus, most states have imposed lockdown and shelter-at-home measures that have disrupted the lives of millions of people and the operations of businesses. Currently, international borders of the country are closed, air travel is curtailed, schools and universities are providing instruction online, in-person church services are cancelled, employees in various sectors have been ordered to work from home, and popular large public events have been suspended (Erlanger, 2020). The economy has been paralyzed as global stock markets have seen the greatest decline since the 2008 financial crisis (Clark, 2020). Most troublingly, the U.S. health care system has been caught unprepared to handle the detection and treatment of the virus (Ely, 2020).

National polls of public opinion indicate that COVID-19 is having a significant impact on the attitudes and emotions of the U.S. population. For example, a national poll conducted by the Pew Research Center from March 3-29, 2020 indicates that Americans see the spread of the coronavirus as a top international threat, along with terrorism and nuclear weapons attacks 
(Poushter \& Fagan, 2020). Due to the global media attention as well as the identification of atrisk populations, altruistic fear_fear for the safety of others (Warr \& Ellison, 2000) — about the coronavirus has become particularly prevalent. That is, the pandemic has caused Americans not only to worry about themselves getting sick, but also to worry about the virus spreading into their communities, affecting the health of their family members. For example, a Gallup Panel survey conducted online between the dates March 30 and April 5, 2020 found that $75 \%$ of the Americans are "very" or "somewhat" worried that they or someone in their family would be exposed to coronavirus (McCarthy, 2020).

Feelings of anxiety, uncertainty, and the stress brought by the pandemic are normal in these circumstances (Gordon, 2020). In fact, fear is an adaptive response in the presence of danger; it is functional because it motivates us to engage in protective behavior. However, excessive fear has been linked to negative outcomes, causing poor mental and physical health (Haynes \& Rader, 2015; Kubzansky \& Kawachi, 2000), such as social withdrawal/isolation from others as well as engaging in unnecessary avoidance and protective behaviors (e.g., stockpiling of firearms) (Drakulich, 2015; Vacha \& McLaughlin, 2000).

Fear of the coronavirus has also proved itself particularly capable of the same detrimental impact that is already noted in the fear of crime literature. The randomness of the infection, feelings of uncertainty about what could happen in the upcoming weeks (perceived lack of control), coupled with the fact that there is currently no vaccine or preventative treatment have led people to behave in ways that are disproportionate to the risk caused by this disease (Robinson, 2020). Some of these reactions have been relatively benign, such as rushing to grocery stores and pharmacies for panic buying of months' worth of supplies including rice, 
toilet paper, hand sanitizers, surgical masks, gloves, face shields, and even respirators (Timsit, 2020; Wetsman, 2020).

Unfortunately, some other behaviors exhibited have been divisive and dangerous in nature. For example, since the outbreak reached United States, anti-Asian and anti-immigrant sentiments have been on the rise, as the virus was described distinctly by some high-level officials, including the President, as the "Chinese virus" (Earle, 2020; Fischoff, 2020). Additionally, some politicians have exploited the coronavirus crisis to intensify their attacks on immigrants and refugees, arguing that the contagion occurred because of open borders and migrants, even though experts repeatedly stated that the virus came to the United States by travelers and tourists (Earle, 2020; Tepperman, 2020). Actions such as these, as well as the partisan gap observed in reactions to COVID-19-with Republican governors being slower to respond to the crisis than Democratic ones, Republicans being overwhelmingly more likely than Democrats to believe that President Donald Trump's response to the crisis has been excellent or good, and Democrats viewing the virus as a more serious threat than Republicans - illustrate that the coronavirus has become a moral and political issue (Adolph et al., 2020; Newport, 2020).

Furthermore, while the full psychological impact of the COVID-19 crisis is still unknown, research on other macro-level stressors such as other pandemics, natural disasters, and terrorism, suggests that excessive worry can produce even more severe physical and psychological consequences (Garfin, Silver, \& Holman, 2020; The Lancet, 2005). For example, after a major earthquake hit Turkey in 1999, many survivors refused to go back into their homes and instead lived in outdoor camps for several months. Therefore, it is important to understand who is most at risk for experiencing excessive worry in order to address its consequences. 
In this context, we draw on data from a national survey to (1) evaluate levels of both personal fear and altruistic fear about COVID-19 in the United States, (2) identify social patterns in the experience of these fears, and (3) assess the impact that fear of the coronavirus has on psychological well-being. We build our models of personal and altruistic fear based on the vulnerability perspective within the fear of crime and terrorism literature and incorporate insights from Moral Foundations Theory to address the moral and political aspects of the pandemic. We then examine the implications of elevated fear of COVID-19 as a macro-level stressor with the potential for mental health consequences. In doing so, we identify factors that contribute to variation in the experiences of fear-both personal and altruistic - and its consequences.

\section{Fear of COVID-19}

\section{The Significance of Fear}

Fear is a primary emotion (Kemper 1987). It is universally experienced and provides the basis upon which many more complex emotional experiences such as anxiety, panic, and terror, are formed (Turner, 2014). Fear also has survival value - it signals danger or a threat to one's self-interest or social group and precipitates a fight-or-flight response (Kemper, 1987; Barbalet, 2001). Thus, in the context of the current coronavirus crisis, the experience of fear is functional for individual and societal well-being. Fear may lead individuals to engage in behaviors such as handwashing and social distancing that can limit the spread of illness. Conversely, fear of disease may have undesirable consequences such as avoiding contact with health care services when needed or scared but healthy individuals utilizing services when unneeded (Barrett \& Brown, 2008; McDonnell, Nelson \& Schunk, 2012; Yang, 2008). On an individual level, excessive disease-related fear can lead to more serious psychological distress, interference with 
cognitive processing, and diminished physical health (Garfin, Silver, \& Holman, 2020; Richman, Cloninger, \& Rospenda, 2008; Shultz et al. 2016).

At the societal-level, fear can characterize an "emotion climate" - a climate of fear (de Rivera 1992). Defined as “collective emotions experienced as a result of a society's response to its sociopolitical conditions" (Bar-Tal, Halperin, \& Rivera, 2007, p. 443), emotion climates may dominate the behaviors of the public (de Rivera, 1992). Although climates of fear can result from transitional contexts, which are temporary in duration, the fear itself can have long term impacts on society, lasting well beyond the context in which it developed (Bar-Tal, Halperin, \& de Rivera, 2007). Fear-based emotional climates can be seen among citizens of dictatorships or in regions characterized by political violence or frequent terrorist attacks. Fear in these cases serves to isolate individuals (de Rivera, 1992). In a similar way, the uncertainty caused by the COVID-19 pandemic may lead to a climate of fear within the United States and across the globe. Although governments have mandated social isolation in many regions, in a climate of fear, social isolation will continue to persist after the risk of infection has substantially declined.

Furthermore, even in relatively secure environments, including the United States, social scientists have noted the use of fear by politicians and the media to manipulate the public and achieve political goals (Altheide, 2017; Best, 2018; Glassner, 1999; Stearns, 2006). In the case of terrorism, for example, research has found positive associations between the extent of news media consumption and fear of terrorism (Matthes, Schmuck, \& von Sikorski, 2019; Nellis \& Savage, 2012). While research on the impacts of the COVID-19 pandemic is only beginning to emerge, in academic commentaries mental health experts have cautioned the research community about the association between media consumption and fear of the virus (Asmudson \& Taylor, 2020; Garfin, Silver, \& Holman, 2020). Indeed, analyses of survey data collected 
from an international convenience sample found a significant positive association between media exposure and fear of COVID-19, net of demographic characteristics and perceived risk of infection (Mertens et al., 2020).

\section{Individual-level Predictors of Fear}

An extensive body of criminological research has examined fear of crime, and more recent studies have extended this research to understand fear of terrorism (Lane et al., 2014; Nellis, 2009, Nellis \& Savage, 2012). While crime (including acts of terrorism) and pandemics are clearly distinct in their scale and origins, the uncertainty of both categories of adverse events suggests the applicability of fear of crime models. ${ }^{1}$ In addition, as with crime, and terrorism more specifically, infectious disease presents a potential to harm in a manner in which individuals have little control. Indeed, the state of fear caused by the COVID-19 crisis has been likened to the fear of terrorism. As described by Julianne Smith, former deputy national security advisor to Vice President Joe Biden, "there is a similar sense of helplessness... You don't know when terrorism or the pandemic will strike, so it invades your personal life. With terror, you worry about being in crowds and rallies and sporting events. It's the same with the virus crowds spell danger" (Erlanger, 2020). Thus, in our effort to identify predictors of fear of COVID-19, we draw on this criminological research on fear.

Fear of crime can be differentiated into two types - personal fear (fear for oneself) and altruistic fear (fear for others) (Warr \& Ellison, 2000). Although studies have found that altruistic fear is more prevalent (Drakulich, 2015; Snedker, 2006), most fear of crime research focuses on personal fear. Both types of fear are relevant in the case of COVID-19-individuals may be concerned that they, themselves will become infected with the virus or that others will suffer from virus-related consequences. In fact, the emphasis placed on social distancing, 
cautions regarding asymptomatic spread of the disease, and public health guidance to act as if you are carrying the virus to limit infecting others (e.g., NYC.gov, 2020; CDCa, 2020), suggest that altruistic fear may be particularly salient.

\section{Vulnerability and Fear, Personal and Altruistic}

Within the fear of crime literature, an extensive amount of research focuses on the vulnerability perspective regarding personal fear. According to this perspective, personal fear of crime is greater among individuals who are perceived to be more vulnerable to victimization (Lane et al., 2014; Wyant, 2008). At the individual level, women experience greater fear of crime relative to men, even if their actual risk of victimization may be low (Hale, 1996; Henson \& Reyns, 2015; Warr, 1984, 2000). Presumably, women may feel more threatened by crime due to a perceived inability to defend themselves physically, with the threat of sexual or physical assault especially concerning (Ferraro, 1995; Hirtenlehner \& Farrall, 2014; Jackson, 2009). Non-Whites and persons from lower socioeconomic status have also tended to report greater fear of crime, though the research findings have been less clear for these variables than those for gender (Lane et al., 2014). Likewise, early research had identified a positive association between age and fear of crime, due to increasing physical vulnerability (LaGrange \& Ferraro, 1989; Warr, 1984), though later research suggests a negative or curvilinear relationship between age and fear (Chadee \& Ditton, 2003; Farrall et al., 2000).

Studies of terrorism-related fear have identified similar patterns. For example, in a 2006 survey of residents of New York City and Washington, DC, Nellis (2009) found that women reported greater fear of terrorism than men, and fear of terrorism was positively associated with perceived risk of victimization. Similarly, in a 2018 national survey of Americans, Haner and colleagues (2019) found women to be more fearful of terrorism than men. The survey also found 
that fear of terrorism was more prevalent among non-Whites, those expressing emotional vulnerability, and political conservatives (Haner, Sloan, Cullen, Kulig, \& Jonson, 2019). Thus, in addition to supporting the fear of crime literature, with women, non-Whites, and the emotionally vulnerable being more fearful (Eisenman et al, 2009; Lane et al. 2014; Lorenc et al., 2012), Haner and colleagues' (2019) findings also indicate a political component to fear of terrorism (Altheide, 2017; Gadarian, 2013; Jackson, 2011).

The studies that have examined altruistic fear of crime have also consistently found that fear for others is gendered (Warr \& Ellison, 2000). More specifically, women report greater fear about crime for themselves and for their children than do men. On the other hand, men are more fearful of crime for their spouse or significant other than are women (Drakulich, 2015; Haynes \& Rader, 2015; Nellis \& Savage, 2012). In addition, within families, parental fear tends to be directed more towards daughters than sons (Warr \& Ellison, 2000). That females are more likely to be the target of altruistic fear than males is consistent with the vulnerability perspectivefemales are perceived as more vulnerable to victimization and thus deserving a greater focus of one's concerns (Drakulich \& Rose, 2013). Despite having different antecedents, however, the extant research suggests that both personal and altruistic fear may be associated with reduced psychological well-being (Drakulich, 2015; Lorenc et al., 2012; Warr \& Ellison, 2000).

Furthermore, beyond these demographic antecedents of fear of crime, research indicates that an individual's perception of risk of victimization is a substantial contributor to personal fear of crime (Jackson, 2011; Warr, 2000), if not the "most important determinant of fear of victimization" (Ferraro, 1995, p.60). That is, fear is higher among those who believe they are likely to be victimized. Moreover, although much of the fear of crime literature examines direct effects of demographic characteristics on fear, research suggests that women's increased fear of 
crime may be due to their elevated perception of risk (Chataway \& Hart, 2019; Jackson, 2009). That is, women tend to believe they face a greater risk of victimization than men, which results in their higher levels of fear of crime. Again, most of the focus has been placed on understanding personal fear; however, a national survey of personal and altruistic fear of crime found that perceived neighborhood safety, a proxy perceived risk, was significantly associated with fear of crime for family and friends (Haynes \& Rader, 2015). Given that the media coverage of the pandemic as well as public health messaging has emphasized "at risk" populations, perceived risk for others may likely affect altruistic fear (McCarthy, 2020).

\section{The Political and Moral Context of COVID-19}

As with the case of terrorism, noted above, as well as crime more generally (Beckett \& Sasson, 2004; Loo \& Grimes, 2004), emerging research suggests that political factors are likely to influence Americans' fear of COVID-19. For example, following President Donald Trump's downplaying of the threat of the virus (Cillizza, 2020; Leonhardt, 2020), an analysis of statelevel responses to the pandemic revealed that states with Republican governors and those with greater numbers of Trump supporters were slower than others to adopt social distancing policies (Adolph et al., 2020). Likewise, recent survey data show that Republicans expressed less concern about COVID-19 and were less likely to follow the recommendations of the Centers for Disease Control than their Democrat counterparts (McCarthy, 2020), while analyses of cell phone data illustrated significantly less compliance with social distancing guidelines in predominantly Republican counties than in Democratic counties (Allcott et al., 2020).

Furthermore, the recent protests against statewide coronavirus stay-at-home orders, with the chant "Give me Liberty or Give Me COVID-19" (e.g., Associated Press, 2020), suggest that governmentally enforced restrictions on citizens has struck more deeply-rooted values. Thus, the 
coronavirus crisis also appears to have a moral component. As such, Moral Foundations Theory (MFT) may provide insight into the psychological underpinnings of differential responses to the coronavirus crisis (Graham et al., 2013; Haidt, 2012). According to MFT, moral concerns can be categorized into the following five universal foundations: harm/care, fairness/reciprocity, ingroup/loyalty, authority/respect, and purity/sanctity (Haidt \& Graham, 2007). The existence of these foundations is innate, though an individual's emphasis on each is shaped by culture, social institutions, and experiences (Haidt et al, 2009). The first two foundations center on protecting the individual ("individualizing foundations") — having compassion for others and defending civil liberties — while the other foundations locate moral concerns at the group level ("binding foundations") — sacrificing the self for group order, showing obedience to authority, and maintaining normative behaviors (Graham, Haidt, \& Nosek, 2009). Empirical research suggests that what we observe as political gaps in interpretations of social issues stems from divergence on these moral foundations, with liberals tending to approach issues from an individualizing perspective and conservatives tending to be more binding-oriented in their concerns (Graham et al., 2009; Koleva et al., 2012; Milesi \& Alberici, 2018; Wolsko, Ariceaga, \& Seiden, 2016). Although the research that links MFT to emotional experience has tended to focus on moral emotions such as disgust (Inbar, Pizarro, \& Bloom, 2012, Inbar et al., 2012) or anger (Hutcherson \& Gross, 2011; Russell \& Giner-Sorolla, 2011), the political context of the coronavirus crisis in the United States suggests that experiences of personal and altruistic fear of the virus may relate to these moral foundations. More specifically, we may expect that fear about oneself or others becoming ill will be more salient for persons high on individualizing foundations, which increase concern for human suffering (Süssenbach, Rees, \& Gollwitzer, 2019). These fears surround the potential for harm to self or others caused by the virus as well as 
the need to respect the welfare of others by protecting oneself and social distancing (Clark et al., 2017; Wolsko, Ariceaga, \& Seiden 2016). Moreover, while those with a binding-orientation are less concerned with the individual in general, following the authority of Donald Trump's lead, and his relatively dismissive approach to the crisis (e.g., Cilizza, 2020), may further decrease personal and altruistic concerns among those who emphasize binding foundations. Therefore, we seek to extend the extant research on socially patterned fears by applying these insights from MFT and by examining the mental health impact of excessive fear of COVID-19.

\section{Fear and Mental Health}

As defined in the sociological literature, stressors are "conditions of threat, challenge, demands, or structural constraints that, by the very fact of their occurrence or existence, call into question the operating integrity of the organism" (Wheaton \& Montazer 2010, p. 173) and, as such can lead to psychological distress in individuals. A pandemic, as either a traumatic event to those personally affected by illness or as a more general threat, meets this definition. Furthermore, a pandemic is a stressor that occurs at the macro-level of social reality. Unlike the case for stressors at the micro-level (e.g., divorce) or meso-level (e.g., neighborhood crime), with macro-level stressors, "each member of the unit, by definition, is exposed at some level, although the level of exposure may vary by time and place" (Wheaton et al., 2013, p. 307).

According to the stress process model, whether or not the presence of a stressor will result in the experience of physical or psychological changes in an individual depends on contextual factors (e.g., social circumstances or life experiences) (Pearlin \& Bierman, 2013; Wheaton \& Montazer, 2010). As fear arises from the perception of threat, the intensity of fear and worry about COVID-19 can signify the perceived threat of the virus (Malik et al., 2018; Nellis, 2009; Richman et al., 2008). That is, the presence of elevated fear of COVID-19 
indicates virus-related stress. This stress, then, can lead to decreased mental health (Pearlin \& Bierman, 2013). Furthermore, variation in this fear experience, may correspond to variation in the psychological outcomes of the perceived stress of COVID-19.

In the analyses that follow, we assess the extent of both personal and altruistic fear of COVID-19 reported in our sample, social patterns in the experience of these fears, and the association between coronavirus-related fear and decreased mental health. We build on the research discussed above by evaluating the impact of structural vulnerability, perceived risk, moral/political factors, and news awareness on personal and altruistic fear of COVID-19.

\section{Methods}

\section{Sample}

Respondents for this study were recruited using Amazon's Mechanical Turk (MTurk) program for a national level survey that was fielded between March $28^{\text {th }}$ and $29^{\text {th }}, 2020$. MTurk and other opt-in online surveys has become common in social science research due to their dataquality advantages - limiting interviewer effects, non-response, satisficing, and speeding (Anson, 2018; Hauser \& Schwarz, 2016; Weinberg et al., 2014). At the time of our survey, 123,653 individuals had been diagnosed with COVID-19 within the United States and 2,135 Americans had died due to the virus (New York Times, 2020). Furthermore, 26 states had put "stay-athome" orders in place, and warnings about social distancing were ubiquitous (Mervosh, Lu, \& Swales, 2020). MTurk allows respondents ("workers") to opt-in to participation in activities (human intelligence tasks, or HITs), including surveys, in exchange for small financial incentives. For our survey, we limited respondents to those who had a 95\% successful completion rate for HITs and had completed over 500 HITs (Peer, Vosgerau, \& Acquisti, 2014) and were 18 years or older and resided within the United States. 
The final analytic sample was reduced from 1,000 to 990 respondents due to listwise deletion of cases with missing values $(<5 \%)$. The final sample was $68.8 \%$ White, $40.6 \%$ female, 45.4\% married, with an average age of 38.37 years. This sample corresponds roughly to the to the demographic composition of respondents to the 2018 American Community Survey, which was $72.2 \%$ White, $50.8 \%$ female, $47.8 \%$ married, and 46.9 years old on average. Furthermore, $28.7 \%$ of the sample identified as Republican, which is close in comparison to the PEW Research Center estimate of $26 \%$ of the American population being Republican.

\section{- Insert Table 1 about here-}

\section{Dependent Variables}

Personal Fear. We measured personal fear of COVID-19 with six items that evaluated the respondent's worry of various situations involving the virus (e.g., being exposed to the virus, dying from the virus) using a four-item Likert scale ranging from "not worried at all" to "very worried." We combined the items to produce an averaged scale of personal fear $(\alpha=.901$, factor loadings: .527 to .899$)$. See Table 2 for item wordings and responses.

The fear of crime literature frequently measures fear as a respondent's extent of worry about crime (Clay-Warner, 2014; Farrall, Jackson, \& Gray, 2009). Warr and Ellison (2000) explain that worry measures "anxiety about future victimization" rather than concern about an immediate threat (p. 557). In the study of fear of COVID-19, it is most appropriate to assess worry about future victimization, as the immediate threat of the virus to most Americans was uncertain, particularly at the time of data collection. The use of worry to assess fear of victimization is, accordingly, consistent with previous research (Brunton-Smith \& Sturgis, 2011; Lane \& Meeker, 2000; Nellis, 2009). 
Altruistic Fear. We measured altruistic fear, or fear about others becoming ill from COVID-19, using an averaged scale of seven items that evaluated the respondent's frequency of worry about other people becoming sick with the virus. Respondents rated each item using a four-point Likert scale of the frequency of worry, which ranged from "very rarely" to "very often" ( $\alpha=.912$, factor loadings: .781 to .854). See Table 2 for item wordings and responses. This procedure of asking respondents to rate worry about listed individuals or groups of others is consistent with the measurement of altruistic fear in the extant research (Drakulich, 2015; Warr \& Ellison, 2000).

Mental Health Harm. We assessed the mental health impact of COVID-19 by responses to the following question: "Do you feel that worry or stress related to coronavirus has had a negative impact on your mental health, or not?" "Yes" responses were coded as 1 and "no" was coded as 0 , so that a value of 1 indicates a perceived decline in mental health due to COVID-19.

\section{Independent Variables}

Vulnerability Factors. Following the fear of crime literature, we include the structural vulnerability characteristics of gender, age, and race in our models. We coded self-identified females as 1 and males as 0 . Age is measured in years. We measure race dichotomously, with Whites coded as 1 and non-Whites coded as 0 .

Perceived Risk. Previous research has documented the tie between perceived risk of victimization and fear (Nellis, 2009; Rader, May, \& Goodrum, 2007). Thus, we include perceived risk of dying from COVID-19 in our models. We assessed perceived risk by responses to the question: "In your best judgment, what is the percent chance (or chances out of 100) that each of the following would DIE if they GOT INFECTED with the coronavirus?" Participants responded to this question for the following groups: you personally, the average American, 
children under 12 , elderly people, people with an underlying medical problem, and people with auto-immune disorders. The ordinal set of response options ranged from "under 1\%" to "over $40 \%$ " on a seven-point scale. For the analyses of personal fear, we use responses to "you personally," and for the analyses of altruistic fear we use the average of responses to the other groups $(\alpha=.864)$.

Political and Moral Context. We measure the political views of respondents in multiple ways. First, we include respondents' self-reported affiliation with the Republican Party (yes=1). Second, we measure the political views of respondents with a five-point scale ranging from "very liberal" to "very conservative" (Baranauskas \& Drakulich, 2018; Enns \& Ramiriez, 2018). Third, due to the observed protests regarding personal liberty as well as research that suggests Libertarians prioritize rationality over emotionality and score high on the moral concern of liberty while ranking low on other concerns (Associated Press, 2020; Iyer et al., 2012), we use a three-item Libertarian scale that evaluated respondents' preference for Libertarian views (i.e., small government, free markets) verses non-libertarian views (i.e., greater government role). Higher responses on this variable indicate more agreement with libertarian views $(\alpha=.739)$ (Filindra \& Kaplan, 2016). Fourth, to capture the unique impact of Trump's presidential influence (e.g., Haner et al., 2020), we include a measure of general faith in Trump. This is a mean index based on five items that asked about general attitudes towards President Trump (e.g., "I believe that President Trump will make America great again.") Respondents rated each statement on a five-point scale $(1=$ strongly disagree, $5=$ strongly agree $)(\alpha=.968$, factor loadings: .923 to .958$)$.

Finally, following Graham and colleagues' (2009) assessment of MFT, we created indices derived from 20 items that asked about moral foundations, each rated on a five-point 
scale $(1=$ strongly disagree, $5=$ strongly agree $)$. The items included four variables for each of the following five moral foundations: fairness/reciprocity (e.g., "Justice, fairness, and equality are the most important requirements for a society", $\alpha=.775$, factor loadings: .468 to .773 ), harm/care (e.g., "Compassion for those who are suffering is the most crucial virtue", $\alpha=.639$, factor loadings: .412 to .507), ingroup/loyalty (e.g, "People should always put their group's interests above their own personal interests", $\alpha=.721$, factor loadings: .434 to .791 ), authority/respect ("Respect for authority is something all children need to learn", $\alpha=.859$, factor loadings: .650 to .823), and purity/sanctity ("I would call some acts wrong on the grounds that they are unnatural", $\alpha=.924$, factor loadings: .843 to .866 ). Factor analysis revealed that the items loaded on the two expected factors, representing individualizing foundations (including harm/care and fairness/reciprocity; factor loadings $=.636$ and .658$)$ and binding foundations (including ingroup/loyalty, authority/respect, and purity/sanctity; factor loadings $=.634$ to .818 ) . Following previous research, we averaged the two individualizing indices to create an overall individualizing foundations index $(\mathrm{r}=.527)$ and averaged the three binding indices to create an overall binding foundations index $(\alpha=.794)$ (Malka et al., 2016; Smith et al., 2014; Van Leeuwen \& Park, 2009). The wording of each item is presented in the Appendix.

News Awareness. Since previous research documents a positive association between adverse event-related news consumption and fear (Asmudson \& Taylor, 2020; Garfin, Silver, \& Holman, 2020; Nellis \& Savage, 2012), we include a measure of news awareness about the COIVD-19 outbreak. Participants responded to the question: "How closely have you been following news about the outbreak of the coronavirus strain known as COVID-19?" on a fourpoint scale that ranged from "not closely at all" to "very closely."

\section{Control Variables}


We include the following demographic controls in all models: education (measured ordinally: 1 = "less than high school degree" to 7 = "Doctoral degree"), marital status ( $1=$ married , $0=$ other), 2018 annual household income (measured ordinally: $1=$ " $0-\$ 9,999 "$ to $7=$ "\$100,000+"), and identification with a religious group $(1=y e s)$. We also include a control for residing in the geographic South $(1=y e s, 0=n o)$, as regional cultural and political factors, such as increased adherence to Donald Trump's messaging, may influence fear of COVID-19.

In addition, following Gottfredson and Hirschi's (1990) general theory of crime, research has shown that low self-control is a consistent predictor of victimization (Kulig et al., 2019; Pratt et al., 2014) and perceptions of risk and fear (Galliot, Meichel, \& Baumeister, 2006), and thus may relate to fear of COVID-19. Thus, we include a measure of low self-control, assessed with the average of six items (e.g., "I often act on the spur of the moment without stopping to think") derived from Grasmick and colleague's (1993). Respondents rated the items on a five-point Likert scale ranging from "Strongly disagree" to "Strongly agree." Higher values indicate lower self-control ( $\alpha=.875$, factor loading: .723 to .818).

Finally, we include two variables to control for exposure to COVID-19. Respondents answered "yes" (coded as 1) or "no" (coded as 0) to the following two questions: "To the best of your knowledge, have any of your friends or family members been infected with the coronavirus?" and "Do you believe that you have been infected with the coronavirus?"

\section{Analytic Strategy}

First, in order to assess the overall sense of concern about different aspects of the COVID-19 situation, we examine frequencies of responses to each personal and altruistic fear item. Second, we use Ordinary Least Squares (OLS) regression to predict personal fear and altruistic fear by the sets of vulnerability characteristics, political factors, and control variables. 
We model these regressions in two steps. The first model includes the demographic vulnerability characteristics, political factors, and control variables. The second model adds perceived risk to the analysis - personal risk for personal fear, and risk for others for altruistic fear. This strategy enables us to assess the impact of risk as a potential mediator of the relationships between the independent variables and fear (Jackson, 2009, 2011). Third, in order to assess the mental health impact of coronavirus fear, we estimate binary logistic regressions of mental health harm in two models. First, we predict mental health harm with all independent variables and controls. Then, we add the fear variables to the model. Across all models, variance inflation factor scores ranged from 1.05 to 2.75 , which suggest that multicollinearity was not a concern in the analyses (Cohen et al., 2003).

It is necessary to note that our cross-sectional data do not enable us to make causal interpretations of the relationships examined here. However, we can be confident that most of our independent variables precede fear of COVID-19 (e.g., gender, age, political orientation), and the extant research on fear of crime indicates that perceived risk is a key antecedent of fear of victimization (Ferraro, 1995; Jackson, 2011; Warr, 2000).

\section{Results}

Table 2 reports the frequencies of responses to each personal and altruistic fear item. The final column of the table shows the percentages of the sample that responded with "somewhat worried" or "very worried" to the item. As shown in the top panel for the personal fear items, most respondents were worried about COVID-19. Approximately three-fourths of the sample was personally worried about being exposed being exposed to the virus (78\% worried), becoming sick from the virus (76\% worried), and becoming seriously ill (72\% worried). A striking $61 \%$ of the sample was personally worried about dying from the virus. Furthermore, 
about $67 \%$ of the sample was worried about having long-term health problems due to the virus, with 38\% indicating that they were "very worried" about such long-term health effects. This level of worry suggests a dominant presence of personal fear in the American population at the time of data collection (March $28-29,2020$ ), notably early in the timeline of the course of COVID-19 in the United States.

The bottom panel of Table 2 reports the statistics for the altruistic fear items. As described above, respondents indicated the frequency of their worry about different groups of people becoming sick from the virus; thus, the frequencies for altruistic fear reported in Table 2 are not directly comparable to those for personal fear. Nevertheless, as with personal fear, we see a substantial amount of altruistic fear among those in our sample. About 6 out of 10 respondents reported that they worry "often" or "very often" about their family members, elderly persons they know, and doctors and nurses. Half of the sample worried often about "people across American" in general. Respondents had the least amount of overall worry for their neighbors (35\% worried) and persons in other countries (40\% worried). Taken together, these statistics reveal that COVID-19 - and its potential effects on themselves and others - is a major concern for most of our sample. Next, we examine potential sources of variation in this concern.

\section{-Insert Table 2 about here-}

Table 3 presents the results of the OLS regressions of personal fear and altruistic fear. Overall, these analyses reveal that, consistent with the fear of crime literature, perceived risk of dying from COVID-19 is the strongest predictor of personal fear of the virus $(\beta=.266)$. Aside from perceived risk, the analyses also reveal some expected patterns.

Among the vulnerability factors shown in Model 1 of Table 3, women report significantly higher levels of personal fear of COVID-19 than men $(\beta=.091)$, and Whites report significantly 
lower levels of personal fear than non-Whites $(\beta=-.148)$. With inclusion of perceived risk of COVID-19 in Model 2, however, the coefficient for female becomes non-significant. Additional analyses (not shown), demonstrated that women perceive greater risk of dying from COVID-19 than men $(b=.268$, se $=.107, p=.012)$, net of the other predictors. Together, these findings suggest that women are more personally fearful about COVID-19 than men because they perceive their risk of dying from the virus to be greater (Baron \& Kenny, 1986). To confirm this mediation effect, we used the PROCESS procedure in SPSS, developed by Hayes (2017). The results illustrate a significant indirect effect of gender on personal fear through perceived risk (Sobel test $\mathrm{Z}=2.69, \mathrm{p}<.01$; full results are available upon request). Thus, these findings support a mediation model of gender and fear (Jackson, 2009). Also, across both models, age is not a significant predictor of personal fear. ${ }^{2}$

Beyond the vulnerability factors, both Models 1 and 2 of Table 3 reveal fairly consistent political influences on personal fear. As expected, given Libertarians' emphasis on rationality over emotionality (e.g., Iyer et al., 2012), high scores on the Libertarian measure correspond to lower levels of personal fear of COVID-19 $(\beta=-.201)$. Also as expected, there is a significant positive association between individualizing foundations and personal fear $(\beta=.197)$. That is, persons who value compassion and justice for others report greater personal worry about the coronavirus, net of perceived risk and the controls. Unexpectedly, however, persons who score high on binding foundations - those that emphasize respect for authority and ingroup loyaltyalso have elevated levels of personal worry about COVID-19 $(\beta=.130)$.

Both models also show that news awareness is positively associated with personal fear ( $\beta$ $=.174)$. As predicted, attention to coronavirus-related news corresponds to increase levels of personal worry about the virus. In addition, low levels of self-control correspond to heighted 
personal fear of COVID-19 $(\beta=.108)$. Overall, Model 2 of Table 3 explains almost 30\% of the variation in personal fear of the coronavirus.

We see a similar pattern of associations in the regression of altruistic fear, presented in Models 3 and 4 of Table 3. Perceived risk for others is significantly associated with heightened altruistic fear $(\beta=.105)$, although it is not the strongest predictor in the model. Neither gender nor age are significant predictors of altruistic fear. While age is positively associated with altruistic fear in Model 3, this effect does not hold net of perceived risk for others in Model 4, and subsequent analyses did not support a mediation effect. ${ }^{3}$

Also similar to the case with personal fear, those identifying with Libertarian perspectives tend to report lower levels of altruistic fear $(\beta=-.118)$, and greater endorsements of binding foundations and individualizing foundations both correspond to heightened levels of altruistic fear $(\beta=.167$ and $\beta=.286$, respectively). News awareness is also positively associated with altruistic fear $(\beta=.172)$.

There are two notable differences, however, between the regressions of personal fear and altruistic fear. First, although faith in Trump was not significantly associated personal fear, it is a significant negative predictor of altruistic fear, net of perceived risk and the other variables $(\beta=$ -.118). Thus, persons with greater faith in Trump have lower levels of coronavirus-related fear for others. This finding suggests the effect of Donald Trump as one that limits concern for others. Second, whereas low self-control was a positive predictor of personal fear, it is a negative predictor of altruistic fear $(\beta=-.136)$, a competitive mediation effect revealed by the inclusion of perceived risk for others in Model 4. Individuals with low self-control, then, fear for themselves in regard to COVID-19, but once perceived risk is accounted for, fear less for others 
relative to those with greater self-control. Approximately $31 \%$ of the variation in altruistic fear is explained by the predictors included in Model 4.

\section{—Insert Table 3 about here-}

We next examine mental health harm as an outcome of personal and altruistic fear, as shown in Table 4. Overall, as expected, personal fear is positively associated with self-reported reduced mental health $(\mathrm{OR}=2.391)$, as shown in Model 2. However, altruistic fear of COVID19, net of personal fear and the other predictors, is not significantly associated with self-reported mental health harm. Despite the indication in the fear of crime literature that altruistic fear may be more consequential for well-being than personal fear (e.g., Warr \& Ellison, 2000), coronavirus-related fear for others does not appear to take the same psychological toll on individuals as does fear for one's own well-being.

Although we do not present specific hypotheses regarding mental health harm beyond the influence of fear, Models 2 and 3 of Table 4 reveal that faith in Donald Trump is associated with decreased odds of mental health harm $(\mathrm{OR}=.759)$, suggesting such faith may be a protective factor. ${ }^{4}$ In contrast, news awareness $(\mathrm{OR}=1.575)$ and perceived personal infection with COVID-19 $(\mathrm{OR}=5.056)$ are associated with increased odds of mental health harm. These findings illustrate the magnification of stress through media consumption as well as the mental health impact of believing one has experienced the disease itself.

Also, in accordance with longstanding patterns identified in mental health research (Nolen-Hoeksema, 1990), women have a greater odds of mental health harm than men (OR = 1.417) and age is negatively associated with mental health harm $(\mathrm{OR}=.985)$ (Inaba et al., 2005). Race is also a significant predictor of mental health harm, net of fear in Model 2, with the odds of harm among Whites being 1.55 times those for non-Whites. This finding, together with the 
race effect on personal fear - that non-Whites experience greater personal fear (stress) than Whites but Whites report greater mental health harm - is consistent with the race paradox found in the mental health literature. Although non-Whites are, on average, exposed to more stressors than Whites, they tend to report as good or better mental health (e.g., Mouzon, 2017).

The results reported in Table 4 also suggest some mediation effects, where the inclusion of fear in Model 2 explains apparent effects in Model 1. Both personal perceived risk $(\mathrm{OR}=$ $1.189)$ and binding foundations $(\mathrm{OR}=1.278)$ are associated with increased odds of mental health harm in Model 1. Subsequent analyses using Hayes's (2017) PROCESS procedure indicated that the inclusion of personal fear in Model 2 fully mediated the relationship between perceived risk and mental health harm; that is, perceived risk is linked to greater odds of mental health harm because it is associated with heightened personal fear of COVID-19 (Sobel test Z $=4.95, \mathrm{P}<$ .000). The PROCESS analysis did not, however, indicate significant indirect effects of binding foundations on mental health harm (Sobel test $Z=.397, p=.69$ ).

\section{—Insert Table 4 about here-}

\section{Discussion}

At the time of this writing, with 3.3 million global cases of COVID-19 infection and 235,000 deaths, and over one million U.S. cases, resulting in over 64,000 U.S. deaths, it is clear that the coronavirus pandemic is taking an unprecedented toll on populations around the world (U.S. Department of Labor, 2020; John Hopkins, 2020). Given the potential pervasiveness of fear in a crisis such as this, and the possible consequences of fearing too little or too much, this study sought to understand (1) the extent to which Americans are worried about the coronavirus, both for themselves and for others, (2) how the experience of personal and altruistic fear varies within the population, and (3) the mental health consequences of excessive fear. In our effort to 
study these pandemic emotions, we developed models of personal and altruistic fear based on insights from the fear of crime and terrorism literature as well as the political and moral context of the pandemic. Our analyses make three key contributions to our understanding of COVID-19 and its impact: the findings (1) reveal the levels of both personal and altruistic fear among Americans and how they correspond to patterns identified in the fear of crime literature, (2) show the significance of the political and moral context in which Americans are experiencing the COVID-19 pandemic, and (3) demonstrate the negative mental health outcomes associated with COVID-19 fears.

\section{Fear of COVID-19 in the United States}

First, our survey showed that, to an overwhelming extent, our sample was worried about COVID-19, both for themselves and for others. Most participants reported feeling personally worried about all aspects of the virus, from being exposed to having long-term health problems and dying. Conversely, only about $14 \%$ of the sample indicated that they were "not worried at all" about dying from the virus - the most extreme consequence examined. To place these personal fears in context, a 2018 national survey found $37.5 \%$ of its sample to be afraid of a "pandemic or major epidemic" and 45\% afraid of a terrorist attack. Furthermore, about 35\% of those respondents worried a lot about having a personal health crisis and $25 \%$ worried a lot about being a victim of a violent crime (Haner et al., 2019). While not directly comparable, with almost $78 \%$ of our sample worried about virus exposure and $61 \%$ reporting fear for their lives, it appears that the gravity of the COVID-19 crisis has greatly increased levels of personal fear within the U.S. population. We can expect that the extent of personal fear about the virus has only increased among Americans as the reach of the pandemic grew substantially since the time of the survey. 
Furthermore, in addition to fearing for themselves, most participants also worried often or very often for numerous others including family members, the elderly, and doctors and nurses. The heightened rate of fear about family we observed is consistent with the criminological research's focus on altruistic fear of crime for family members, which has been shown to have significant behavioral (i.e., protective) consequences (Drakulich, 2015; Warr \& Ellison, 2000). Unlike the extant research on altruistic fear of crime, however, we included additional groups about whom individuals may worry, specifically related to COVID-19. Given that the elderly have been identified as an "at risk" population for COVID-19-related death, and doctors and nurses are frontline personnel working with individuals who are infected, the relatively high frequencies of worry about these groups is expected. Notably, however, altruistic fear dropped substantially when participants were asked about neighbors and people in other countries. Apparently, altruistic fear of COVID-19 is limited to those in our close personal circles-family and elderly persons we know—and those putting their lives in danger to serve others (i.e., doctors and nurses). Americans seem to be much less concerned about their neighbors and foreigners.

In addition, our analyses revealed that the vulnerability perspective on the fear of crime is partially relevant to the fear of COVID-19. For example, race appears to matter, with Whites being significantly less personally fearful of the virus than non-Whites. This race difference may relate to reports of a racial disparity, with proportionately greater numbers of COVID-19 infections and deaths among African Americans and Hispanic/Latino persons relative to Whites (CDC, 2020b). In addition, gender exerts an indirect effect on personal fear through perceived risk. Consistent with social psychological models of the fear of crime, gender differences in fear of COVID-19 are due to women's heightened sense of risk victimization (i.e., dying from the 
virus) relative to men (Jackson, 2009). Aside from the effect of perceived risk for others, we do not see the same patterns of vulnerability in the case of altruistic fear.

\section{The Politics of Fear}

Second, our results suggest that the coronavirus pandemic is a political and moral issue and illustrate the applicability of Moral Foundations Theory to fear research more generally. Although most research on the connections between MFT and emotion has focused on the classic moral emotions of disgust, anger, and contempt (Hutcherson \& Gross, 2011; Inbar et al., 2012), our analyses indicate that fear of COVID-19 strikes a moral cord as well. Based on the politicization of the situation and research that grounds political differences in diverging moral foundations (Graham et al., 2009; Graham et al., 2013), we expected to find greater fear among persons who endorse individualizing foundations and less fear among those who endorse binding foundations. However, our analyses revealed that strength of moral judgements, both individualizing and binding in nature, corresponds to heightened personal and altruistic fear of COVID-19. In other words, the coronavirus is a concern — for self and others- for those who value empathy and justice as well as those who merit loyalty, obedience, and purity. The unexpected positive association between binding foundations and fear indicates the relevance of group-level moral concerns about COVID-19 and may relate to the virus's threat to the wellbeing of communities and the nation as a whole. Future research might probe the meaning of these coronavirus-related concerns as they correspond to the different moral foundations.

Also, in a manner consistent with their documented unemotionality and emphasis on rationality (Iyer et al., 2012), Libertarians reported significantly lower levels of both personal and altruistic fear of COVID-19. In addition, we found that greater faith in Trump corresponded to lower levels of altruistic fear. Thus, it appears that, while belief in the president does not 
lessen personal fear, such confidence does correspond to less concern about the welfare of others regarding COVID-19. Conversely, this finding suggests the potential for the amplification of fear for others under conditions of perceived governmental ineffectiveness (i.e., lowered faith in the nation's leadership), as seen in research on previous pandemics (Barrett \& Brown, 2008; Shultz et al., 2016; The Lancet, 2005).

\section{The Consequences of Fear}

Finally, this study demonstrates the negative mental health consequence of COVID-19 fear. Nearly $58 \%$ or our sample indicated that the stress of COVID-19 has had a negative impact on their mental health. Our multivariate analyses further revealed that persons who report higher levels of personal fear of COVID-19 have greater odds of self-reported mental health harm. Following the stress process model (Pearlin \& Bierman, 2013), fear signifies the experience of stress corresponding to the macro-stressor of COVID-19. The consequence of increased stress is increased psychological distress. Given the high levels of personal fear of COVID-19 observed in our sample, this association is particularly concerning. Additional research may examine potential moderators of the relationship between coronavirus fear and mental health, as resources such as social support and coping skills may buffer the effects of stress (Pearlin \& Bierman, 2013). In addition to personal fear, personal exposure to the coronavirus also corresponded to decreased mental health. Thus, not only does the virus physically affect those who become infected, experiencing the virus first-hand appears to lower the mental well-being of infected individuals as well.

The same pattern does not hold for altruistic fear of COVID-19. Net of personal fear and the other predictors, fear for others is not associated with self-reported declines in mental health. The fear of crime literature indicates that altruistic fear may be more consequential for individual 
well-being than personal fear, as it is associated with greater engagement in protective behaviors that can influence the lives of oneself and others (e.g., purchasing a gun) (Warr \& Ellison, 2000). Although our analysis was limited to one measure of self-reported mental health harm, our results suggest that only personal fear has a significant effect on mental health, at least in the context of COVID-19.

We can offer some suggestions for why personal fear, in particular, is distressing for Americans. The severe disruptions that COVID-19 has caused to the lifestyles of Americans and its potential for even more severe consequences—quarantine, severe illness, long-term health effects, and even death—is frightening. It may be the case that the unprecedented lifestyle restrictions Americans are experiencing and the rapidly rising infections and death rates serve to heighten the salience of the virus and its potential effects. Indeed, our results suggest, media exposure (again, increasing the salience of COVID-19) contributes to mental health harm as well. The virus's pervasiveness has shown that it is something that everyone should be concerned about. Furthermore, the impact of personal fear of COVID-19 may be exacerbated by a lack of coping resources. As noted, social support can substantially lessen the negative mental health impacts of stress (Thoits, 2011). With social distancing policies, access to social support may be substantially limited. For example, we are unable to connect to others in-person or physically comfort our friends and family members. This lack of support may exacerbate the mental health impact of personal fear. Additional research may investigate how individuals can obtain effective social support during this time of obligatory social distancing.

In contrast, we identified lowered odds of mental health harm among those with greater faith in Trump. It may be the case that having faith in the nation's leader provides some sense of comfort. As prior research notes, confidence in the government's ability to handle a pandemic is 
critical determinant of the outcomes of the pandemic on the population (Barrett \& Brown, 2008; Shultz et al., 2016; The Lancet, 2005). However, with Trump's recent erroneous claims about potential cures for COVID-19 (Rogers, Hauser, Yuhas, \& Haberman, 2020), current levels of such trust may be low. Indeed, a National Opinion Research Center poll reported on April 23, 2020 that only $23 \%$ of Americans have high levels of trust in the information the president provides to the public regarding COVID-19 (Pace \& Fingerhut, 2020).

\section{Conclusion}

Our findings provide initial insight into the experiences and outcomes of fear of the coronavirus at the point in time of data collection (March 28th and 29th, 2020). However, they must be considered in light of the limitations of our data. Following notable recent research (Barnum \& Solomon, 2019; Pickett et al., 2018; Silver, 2017), we utilized MTurk for our survey distribution. Although this method of data collection enabled us to gather the experiences and attitudes from a diverse sample of Americans with demographic characteristics fairly comparable to those of the 2018 American Community Survey sample, at a critical point in time, the sample is based on convenience rather than probability. Future data collection from national probability samples is necessary to substantiate our findings and confirm their generalizability to the U.S. population. Furthermore, longitudinal data are necessary to verify the causal order of the associations that we identify, and, in particular, the long-term mental health impacts of the COVID-19 crisis.

Nevertheless, our analyses have illustrated patterns in the emotional experiences associated with COVID-19. Given that that data were collected rather early in the virus's timeline within the United States — virus related deaths in the U.S. went from 2,135 at the time of the survey to 64,000 as of this writing - we can expect that COVID-19 related fear only 
continued to rise. For good reason, the public needs to feel concerned about the virus; however, as indicated in previous research on fear as well as our analyses, excessive fear can have negative consequences. Furthermore, a climate of fear has the potential to linger well after the threat has been eradicated and to affect multiple domains of life-from the economy, community, and social engagement to individual health. The high levels of fear noted in this survey, early on in the crisis, suggest the origination of a climate of fear that could dominate American society for quite some time. As implied by the stress process model, certain groups of people - identified here as those with a heightened perception of risk, those that strongly endorse moral foundations, and those who follow the news most closely — may face the greatest risk of experiencing excessive fear.

\section{Endnotes}

${ }^{1}$ In Warr's (2000, p. 454) words, "there is no evidence that fear of crime is qualitatively different from other forms of fear. What differentiates one from another is merely the object or stimulus of fear."

${ }^{2} \mathrm{We}$ also ran the analyses with an age-squared term to test for a curvilinear relationship between age and fear (Rader, 2017). Neither age nor age-squared were statistically significant predictors of fear in these models.

${ }^{3}$ Additional mediation analyses do not support a mediation effect of perceived risk on the relationships between marital status and religion and altruistic fear (available upon request).

${ }^{4}$ In an additional analysis, we tested for an interaction effect of personal fear and faith in Trump on mental health harm. This coefficient was not statistically significant $(b=-.078, \mathrm{se}=.082, \mathrm{p}=.925)$, indicating that faith in Trump does not buffer the negative mental health consequence of extensive personal fear. 


\section{References}

Adolph, C., Amano, K., Bang-Jensen, B., Fullman, N., \& Wilkerson, J. (2020). Pandemic politics: Timing state-level social distancing responses to COVID-19. MedRxiv.

doi: https://doi.org/10.1101/2020.03.30.20046326

Ahorsu, D. K., Lin, C. Y., Imani, V., Saffari, M., Griffiths, M. D., \& Pakpour, A. H. (2020). The fear of COVID-19 scale: Development and initial validation. International Journal of Mental Health and Addiction, 1-9.

Allcott, H., Boxell, L., Conway, J., Gentzkow, M., Thaler, M., \& Yang, D. Y. (2020). Polarization and public health: Partisan differences in social distancing during the coronavirus pandemic. NBER Working Paper, (w26946).

Altheide, D. L. (2017). Terrorism and the politics of fear. Lanham, MD: Rowman \& Littlefield.

Anson, I. G. (2018). Taking the time? Explaining effortful participation among low-cost online survey participants. Research \& Politics, 5, Advance online publication. doi: 2053168018785483.

Asmundson, G. J., \& Taylor, S. (2020). Coronaphobia: Fear and the 2019-nCoV outbreak. Journal of Anxiety Disorders, 70, 102196.

Associated Press (2020, April 19). Protesters Rally against Washington Stay-At-Home Orders. US News. Retrieved from https://www.usnews.com/news/best-states/washington/articles/2020-0419/inslee-takes-trump-to-task-for-fomenting-insubordination

Baranauskas, A. J., \& Drakulich, K. M. (2018). Media construction of crime revisited: Media types, consumer contexts, and frames of crime and justice. Criminology, 56(4), 679-714.

Barbalet, J. M. (2001). Emotion, social theory, and social structure: A macrosociological approach. Cambridge, England: Cambridge University Press.

Baron, R. M., \& Kenny, D. A. (1986). The moderator-mediator variable distinction in social psychological research: Conceptual, strategic, and statistical considerations. Journal of Personality and Social Psychology, 51(6), 1173.

Barnum, T. C., \& Solomon, S. J. (2019). Fight or flight: Integral emotions and violent intentions. Criminology, 57, 659-686.

Barrett, R., \& Brown, P. J. (2008). Stigma in the time of influenza: Social and institutional responses to pandemic emergencies. The Journal of Infectious Diseases, 197(Supplement_1), S34-S37.

Bar-Tal, D., Halperin, E., \& de Rivera, J. (2007). Collective emotions in conflict situations: Societal implications. Journal of Social Issues, 63(2), 441-460.

Beckett, K., \& Sasson, T. (2003). The politics of injustice: Crime and punishment in America. New York, NY: Sage Publications.

Best, J. (2018). American nightmares: Social problems in an anxious world. Berkeley, CA: University of California Press. 
Björgvinsson, T., Kertz, S. J., Bigda-Peyton, J. S., McCoy, K. L., \& Aderka, I. M. (2013). Psychometric properties of the CES-D-10 in a psychiatric sample. Assessment, 20(4), 429-436.

Brunton-Smith, I., \& Sturgis, P. (2011). Do Neighborhoods generate fear of crime? An empirical test using the British Crime Survey. Criminology, 49, 331-370.

Centers for Disease Control and Prevention (2020a, April 20). Interim clinical guidance for management of patients with confirmed coronavirus disease (COVID-19). Retrieved from https://www.cdc.gov/coronavirus/2019-ncov/hcp/clinical-guidance-managementpatients.html\#Asymptomatic

Centers for Disease Control and Prevention (2020b, April 21). COVID-19 in racial and ethnic minority groups. Retrieved from https://www.cdc.gov/coronavirus/2019-ncov/need-extraprecautions/racial-ethnic-minorities.html

Chadee, D., \& Ditton, J. (2003). Are older people most afraid of crime? Revisiting Ferraro and LaGrange in Trinidad. British Journal of Criminology, 43(2), 417-433.

Chataway, M. L., \& Hart, T. C. (2019). A social-psychological process of "fear of crime" for men and women: Revisiting gender differences from a new perspective. Victims \& Offenders, 14(2), 143164.

Clay-Warner, J. (2014). Crime and emotions. In J. E. Stets \& J. H. Turner (Eds.), Handbook of the sociology of emotions: Volume II (pp. 473-493). Dordrecht, Netherlands: Springer.

Cillizza, C. (2020, April 1). 11 times Donald Trump has 'belittled' coronavirus. CNN Politics. Retrieved from https://www.cnn.com/2020/04/01/politics/donald-trump-coronavirus-mike-pence/index.html

Clark, C. B., Swails, J. A., Pontinen, H. M., Bowerman, S. E., Kriz, K. A., \& Hendricks, P. S. (2017). A behavioral economic assessment of individualizing versus binding moral foundations. Personality and Individual Differences, 112, 49-54.

Clark, D. (2020, March 3). Media, fear, and the coronavirus outbreak. Psychology Today. Retrieved from https://www.psychologytoday.com/us/blog/the-runaway-mind/202003/media-fear-and-thecoronavirus-outbreak

Cohen, J, Cohen, P., West, S. G., \& Aiken, L. S. (2003). Applied multiple regression/correlation analysis for the behavioral sciences. Third edition. Lawrence Erlbaum Associates.

de Rivera, J. (1992). Emotional climate: Social structure and emotional dynamics. In K. T. Strongman (Ed.), International review of studies on emotion (pp. 199-218). Hoboken, NJ: John Wiley \& Sons.

Drakulich, K. M. (2015). Concerns for self or family? Sources of and responses to altruistic fear. Journal of Interpersonal Violence, 30(7), 1168-1207.

Drakulich, K. M., \& Rose, K. (2013). Being male or living with a female: Fear for partners by sex and sexual orientation. Journal of Interpersonal Violence, 28(9), 1765-1797. 
Earle, S. (2020, April 16). For the nationalist right, our fear of coronavirus is a political opportunity. The Guardian. Retrieved from https://www.theguardian.com/commentisfree /2020/apr/16/nationalistright-fear-coronavirus-infection-pandemic

Eisenman, D. P., Glik, D., Ong, M., Zhou, Q., Tseng, C. H., Long, A., Fielding, J. \& Asch, S. (2009). Terrorism-related fear and avoidance behavior in a multiethnic urban population. American Journal of Public Health, 99(1), 168-174.

Ely, W. (2020, April 14). Doctors fear the coronavirus. Is that affecting their medical decisions? Washington Post. Retrieved from https://www.washingtonpost.com/outlook/2020/04/14/ doctorsfear-coronavirus-is-that-affecting-their-medical-decisions/

Enns, P. K., \& Ramirez, M. D. (2018). Privatizing punishment: Testing theories of public support for private prison and immigration detention facilities. Criminology, 56(3), 546-573.

Erlanger, S. (2020, April 6). The coronavirus inflicts its own kind of terror. The New York Times. Retrieved from https://www.nytimes.com/2020/04/06/world/europe/coronavirus-terrorism-threatresponse.html

Farrall, S., Bannister, J., Ditton, J., \& Gilchrist, E. (2000). Social psychology and the fear of crime. British Journal of Criminology, 40(3), 399-413.

Farrall, S., Jackson, J. \& Gray, E. (2009). Social order and the fear of crime in contemporary times. New York, NY: Oxford University Press.

Ferraro, K. F. (1995). Fear of crime: Interpreting victimization risk. Albany, NY: State University of New York Press.

Filindra, A., \& Kaplan, N. J. (2016). Racial resentment and whites' gun policy preferences in contemporary America. Political Behavior, 38(2), 255-275.

Fischoff, B. (2020). Speaking of psychology: Coronavirus anxiety. American Psychological Association. Retrieved from https://www.apa.org/research/action/speaking-of-psychology/coronavirus-anxiety

Foster, D. (2016). 'Keep complaining til someone listens': Exchanges of tacit healthcare knowledge in online illness communities. Social Science \& Medicine, 166, 25-32.

Foster, S., Hooper, P., Knuiman, M., \& Giles-Corti, B. (2016). Does heightened fear of crime lead to poorer mental health in new suburbs, or vice versa?. Social Science \& Medicine, 168, 30-34.

Gadarian, S. K, Goodman, S. W., \& Pepinsky, T. B. (2020). Partisanship, health behavior, and policy attitudes in the early stages of the COVID-19 pandemic. Available at SSRN: https://ssrn.com/abstract=3562796

Gailliot, M., Schmeichel, B. J., \& Baumeister, R. F. (2006). Self-regulatory processes defend against the threat of death: Effects of self-control depletion and trait self-control on thoughts and fears of dying. Journal of Personality and Social Psychology, 91(1), 49-62.

Garfin, D. R., Silver, R. C., \& Holman, E. A. (2020). The novel coronavirus (COVID-2019) outbreak: Amplification of public health consequences by media exposure. Health Psychology. Advance online publication. http://dx.doi.org/10.1037/hea0000875 
Glassner, B. (1999). The culture of fear: Why Americans are afraid of the wrong things. Basic Books.

Gordon, J. (2020, March 16). Coping With Coronavirus: Managing Stress, Fear, and Anxiety. National Institute of Health. Retrieved from https://www.nimh.nih.gov/about/director/ messages/2020/coping-with-coronavirus-managing-stress-fear-and-anxiety.shtml

Gottfredson, M. R., \& Hirschi, T. (1990). A general theory of crime. Stanford University Press.

Graham, J., Haidt, J., \& Nosek, B. A. (2009). Liberals and conservatives rely on different sets of moral foundations. Journal of Personality and Social Psychology, 96(5), 1029.

Graham, J., Haidt, J., Koleva, S., Motyl, M., Iyer, R., Wojcik, S. P., \& Ditto, P. H. (2013). Moral foundations theory: The pragmatic validity of moral pluralism. In P. Devine \& A. Plant (Eds.) Advances in Experimental Social Psychology (Vol. 47, pp. 55-130). Cambridge: MA: Academic Press.

Grasmick, H. G., Tittle, C. R., Bursik Jr, R. J., \& Arneklev, B. J. (1993). Testing the core empirical implications of Gottfredson and Hirschi's general theory of crime. Journal of Research in Crime and Delinquency, 30(1), 5-29.

Green, T. V. \& Tyson, A. (2020, April 2). 5 facts about partisan reactions to COVID-19 in the U.S. Pew Research Center. Retrieved from https://www.pewresearch.org/fact-tank/2020/04/02/5-factsabout-partisan-reactions-to-covid-19-in-the-u-s/

Haidt, J. (2012). The righteous mind: Why good people are divided by politics and religion. New York, NY: Vintage.

Haidt, J., \& Graham, J. (2007). When morality opposes justice: Conservatives have moral intuitions that liberals may not recognize. Social Justice Research, 20(1), 98-116.

Haidt, J., Graham, J., \& Joseph, C. (2009). Above and below left-right: Ideological narratives and moral foundations. Psychological Inquiry, 20(2-3), 110-119.

Hale, C. (1996). Fear of crime: A review of the literature. International Review of Victimology, 4(2), 79150.

Haner, M., Sloan, M. M., Cullen, F. T., Kulig, T. C., \& Lero Jonson, C. (2019). Public concern about terrorism: Fear, worry, and support for anti-Muslim policies. Socius, 5, 2378023119856825.

Haner, M., Sloan, M. M., Cullen, F. T., Graham, A., Lero Jonson, C., Kulig, T. C., \& Aydın, Ö. (2020). Making America safe again: Public support for policies to reduce terrorism. Deviant Behavior, 119.

Hauser, D. J., \& Schwarz, N. (2016). Attentive Turkers: MTurk participants perform better on online attention checks than do subject pool participants. Behavior Research Methods, 48, 400-407.

Hayes, A. F. (2017). Introduction to mediation, moderation, and conditional process analysis: A regression-based approach. New York, NY: Guilford Publications.

Haynes, S. H., \& Rader, N. E. (2015). Concerns about crime for self and others: An analysis of individual and contextual effects. Criminal Justice Review, 40(3), 303-321. 
Henson, B., \& Reyns, B. W. (2015). The only thing we have to fear is fear itself... and crime: The current state of the fear of crime literature and where it should go next. Sociology Compass, 9(2), 91-103.

Hirtenlehner, H., \& Farrall, S. (2014). Is the 'shadow of sexual assault' responsible for women's higher fear of burglary? British Journal of Criminology, 54(6), 1167-1185.

Hutcherson, C. A., \& Gross, J. J. (2011). The moral emotions: A social-functionalist account of anger, disgust, and contempt. Journal of Personality and Social Psychology, 100(4), 719.

Inaba, A., Thoits, P. A., Ueno, K., Gove, W. R., Evenson, R. J., \& Sloan, M. (2005). Depression in the United States and Japan: gender, marital status, and SES patterns. Social Science \& Medicine, 61(11), 2280-2292.

Inbar, Y., Pizarro, D. A., \& Bloom, P. (2012). Disgusting smells cause decreased liking of gay men. Emotion, 12(1), 23.

Inbar, Y., Pizarro, D., Iyer, R., \& Haidt, J. (2012). Disgust sensitivity, political conservatism, and voting. Social Psychological and Personality Science, 3(5), 537-544.

Iyer, R., Koleva, S., Graham, J., Ditto, P., \& Haidt, J. (2012). Understanding libertarian morality: The psychological dispositions of self-identified libertarians. PloS One, 7(8).

Jackson, J. (2009). A psychological perspective on vulnerability in the fear of crime. Psychology, Crime \& Law, 15(4), 365-390.

Jackson, J. (2011). Revisiting risk sensitivity in the fear of crime. Journal of Research in Crime and Delinquency, 48(4), 513-537.

Jackson, J., \& Stafford, M. (2009). Public health and fear of crime: A prospective cohort study. The British Journal of Criminology, 49(6), 832-847.

Johns Hopkins (2020). John Hopkins Coronavirus Research Center: COVID-19 global map. Retrieved from https://coronavirus.jhu.edu/map.html

Kemper, T. D. (1987). How many emotions are there? Wedding the social and the autonomic components. American Journal of Sociology, 93(2), 263-289.

Koleva, S. P., Graham, J., Iyer, R., Ditto, P. H., \& Haidt, J. (2012). Tracing the threads: How five moral concerns (especially purity) help explain culture war attitudes. Journal of Research in Personality, 46(2), 184-194.

Kubzansky, L. D., \& Kawachi, I. (2000). Going to the heart of the matter: do negative emotions cause coronary heart disease? Journal of Psychosomatic Research, 48(4-5), 323-337.

Kulig, T. C., Cullen, F. T., Wilcox, P., \& Chouhy, C. (2019). Personality and adolescent school-based victimization: do the big five matter?. Journal of School Violence, 18(2), 176-199.

Kurl, S. \& Korzinski, D. (2020, February 5). Half of Canadians taking extra precautions as coronavirus continues to spread around the globe. Angus Reid Institute. Retrieved from http://angusreid.org/coronavirus/ 
LaGrange, R. L., \& Ferraro, K. F. (1989). Assessing age and gender differences in perceived risk and fear of crime. Criminology, 27(4), 697-720.

Lane, J., \& Meeker, J. W. (2000). Subcultural diversity and the fear of crime and gangs. Crime \& Delinquency, 46(4), 497-521.

Lane, J., Rader, N. E., Henson, B., Fisher, B. S., \& May, D. C. (2014). Fear of crime in the United States: Causes, consequences, and contradictions. Durham, NC: Carolina Academic Press.

Leonhardt, D. (2020, March 15). A complete list of Trump's attempts to play down coronavirus. New York Times. Retrieved from https://www.nytimes.com/2020/03/15/opinion/trumpcoronavirus.html

Loo, D. D., \& Grimes, R. E. M. (2004). Polls, politics, and crime: The law and order issue of the 1960s. Western Criminology Review, 5, 50-67.

Lorenc, T., Clayton, S., Neary, D., Whitehead, M., Petticrew, M., Thomson, H., Cummins, S., Sowden, A., \& Renton, A. (2012). Crime, fear of crime, environment, and mental health and wellbeing: mapping review of theories and causal pathways. Health \& Place, 18(4), 757-765.

Maguen, S., Papa, A., \& Litz, B. T. (2008). Coping with the threat of terrorism: A review. Anxiety, Stress, and Coping, 21(1), 15-35.

Matthes, J., Schmuck, D., \& von Sikorski, C. (2019). Terror, terror everywhere? How terrorism news shapes support for anti-Muslim policies as a function of perceived threat severity and controllability. Political Psychology, 40(5), 935-951.

Malka, A., Osborne, D., Soto, C. J., Greaves, L. M., Sibley C. G., \& Lelkes, Y. (2016). Binding moral foundations and the narrowing of ideological conflict to the traditional morality domain. Personality and Social Psychology Bulletin, 42, 1243-1257.

McCarthy, J. (2020, April 6). Three in four Americans worry about COVID-19 exposure. Gallup. Retrieved from https://news.gallup.com/poll/307646/three-four-americans-worry-covidexposure.aspx

McDonnell, W. M., Nelson, D. S., \& Schunk, J. E. (2012). Should we fear "flu fear" itself? Effects of H1N1 influenza fear on ED use. The American Journal of Emergency Medicine, 30(2), 275-282.

Mertens, G., Gerritsen, L., Salemink, E., \& Engelhard, I. (2020). Fear of the coronavirus (COVID-19): Predictors in an online study conducted in March 2020. Retrieved from https://doi.org/10.31234/osf.io/2p57j

Mervosh, S., Lu, D., \& Swales, V. (2020, April 3). See which states and cities have told residents to stay at home. New York Times. Retrieved from https://www.nytimes.com/interactive/2020/us/coronavirus-stay-at-home-order.html

Milesi, P., \& Alberici, A. I. (2018). Pluralistic morality and collective action: The role of moral foundations. Group Processes \& Intergroup Relations, 21(2), 235-256. 
Mouzon, D. M. (2017). Religious involvement and the Black-White paradox in mental health. Race and Social Problems, 9(1), 63-78.

Nellis, A. M. (2009). Gender differences in fear of terrorism. Journal of Contemporary Criminal Justice, 25(3), 322-340.

Nellis, A. M., \& Savage, J. (2012). Does watching the news affect fear of terrorism? The importance of media exposure on terrorism fear. Crime \& Delinquency, 58(5), 748-768.

Newport, F. (2020, March 20). 10 key findings: Public opinion on coronavirus. Gallup. Retrieved from https://news.gallup.com/opinion/polling-matters/296681/ten-key-findings-public-opinioncoronavirus.aspx

New York Times (2020, April 25). Coronavirus in the U.S.: Latest map and case count. New York Times. Retrieved from https://www.nytimes.com/interactive/2020/us/coronavirus-us-cases.html

Nolen-Hoeksema, S. (1990). Sex differences in depression. Stanford, CA: Stanford University Press.

NYC.gov. (2020). Coronavirus disease 2019 (COVID-19). Retrieved from https://www1.nyc.gov/site/doh/covid/covid-19-main.page

Pace, J. \& Fingerhut, H. (2020, April 23). AP-NORC poll: Few Americans trust Trump's info on pandemic. Associated Press News. Retrieved from https://apnews.com/87f1545cea4b5e8c96e6e902a8d9e9bd

Pearlin, L. I., \& Bierman, A. (2013). Current issues and future directions in research into the stress process. In C. S. Aneshensel, J. C. Phelan, \& A. Bierman (Eds.), Handbook of the sociology of mental health (pp. 325-340). Dordrecht, Netherlands: Springer.

Pickett, J. T., Roche, S. P., \& Pogarsky, G. (2018). Toward a bifurcated theory of emotional deterrence. Criminology, 56, 27-58

Poushter, J. \& Fagan, M. (2020, April 13). Americans see spread of disease as top international threat, along with terrorism, nuclear weapons, cyberattacks. Pew Research Center. Retrieved from https://www.pewresearch.org/global/2020/04/13/americans-see-spread-of-disease-as-topinternational-threat-along-with-terrorism-nuclear-weapons-cyberattacks/

Pratt, T. C., Turanovic, J. J., Fox, K. A., \& Wright, K. A. (2014). Self-control and victimization: A metaanalysis. Criminology, 52(1), 87-116.

Rader, N. E., May, D. C., \& Goodrum, S. (2007). An empirical assessment of the "threat of victimization:" Considering fear of crime, perceived risk, avoidance, and defensive behaviors. Sociological Spectrum, 27(5), 475-505.

Radloff, L. S. (1977). The CES-D scale: A self-report depression scale for research in the general population. Applied Psychological Measurement, 1(3), 385-401.

Richman, J. A., Cloninger, L., \& Rospenda, K. M. (2008). Macrolevel stressors, terrorism, and mental health outcomes: Broadening the stress paradigm. American Journal of Public Health, 98(2), 323-329. 
Robinson, D. (2020, April 1). The fear of coronavirus is changing our psychology. BBC. Retrieved from https://www.bbc.com/future/article/20200401-covid-19-how-fear-of-coronavirus-is-changingour-psychology

Rogers, K., Hauser, C., Yuhas, A., \& Haberman, M. (2020, April 24). Trump's suggestion that disinfectants could be used to treat coronavirus prompts aggressive pushback. New York Times. Retrieved from https://www.nytimes.com/2020/04/24/us/politics/trump-inject-disinfectantbleach-coronavirus.html

Russell, P. S., \& Giner-Sorolla, R. (2011). Moral anger, but not moral disgust, responds to intentionality. Emotion, 11(2), 233.

Shultz, J. M., Cooper, J. L., Baingana, F., Oquendo, M. A., Espinel, Z., Althouse, B. M., Marcelin, L. H., Towers, S., Espinola, M., McCoy, C. B., Mazurik, L., Wainberg, M. L., Neria, Y., \& Rechkemmer, A. (2016). The role of fear-related behaviors in the 2013-2016 West Africa Ebola virus disease outbreak. Current Psychiatry Reports, 18(11), 104.

Silver, J. R. (2017). Moral foundations, intuitions of justice, and the intricacies of punitive sentiment. Law \& Society Review, 51, 413-450.

Smith, I. H., Aquino, K., Koleva, S., \& Graham, J. (2014). The moral ties that bind ... even to out-groups: The interactive effect of moral identity and the binding moral foundations. Psychological Science, $25,1554-1562$.

Snedker, K. A. (2006). Altruistic and vicarious fear of crime: Fear for others and gendered social roles. Sociological Forum, 21(2), 163-195.

Stearns, P. N. (2006). American fear: The causes and consequences of high anxiety. New York, NY: Routledge.

Süssenbach, P., Rees, J., \& Gollwitzer, M. (2019). When the going gets tough, individualizers get going: On the relationship between moral foundations and prosociality. Personality and Individual Differences, 136, 122-131.

Tepperman, J. (2020, March 11). Why are we so scared of the coronavirus? Foreign Policy. Retrieved from https://foreignpolicy.com/2020/03/11/coronavirus-global-panic/

The Lancet (2005). Fear of avian influenza is a double-edged sword. 366(9499):P1751 DOI: 10.1016/S0140-6736(05)67706-9

Thoits, P. A. (2011). Mechanisms linking social ties and support to physical and mental health. Journal of Health and Social Behavior, 52(2), 145-161.

Timsit, A. (2020, March 9). The psychology of coronavirus fear-and how to manage it. Quartz. Retrieved from https://qz.com/1812664/the-psychology-of-coronavirus-fear-and-how-toovercome-it/

Turner, J. H. (2014). The evolution of human emotions. In J. E. Stets \& J. H. Turner (Eds.), Handbook of the sociology of emotions: Volume II (pp. 11-31). Dordrecht, Netherland: Springer. 
U.S. Department of Labor (2020, April 23). News release: unemployment insurance weekly claims. Retrieved from https://www.dol.gov/ui/data.pdf

Vacha, E. F., \& McLaughlin, T. F. (2000). The impact of poverty, fear of crime, and crime victimization on keeping firearms for protection and unsafe gun-storage practices: A review and analysis with policy recommendations. Urban Education, 35(4), 496-510.

Van Leeuwen, F., \& Park, J. H. (2009). Perceptions of social dangers, moral foundations, and political orientation. Personality and Individual Differences, 47, 169-173.

Warr, M. (1984). Fear of victimization: Why are women and the elderly more afraid? Social Science Quarterly, 65(3), 681.

Warr, M. (2000). Fear of crime in the United States: Avenues for research and policy. Criminal Justice, 4(4), 451-489.

Warr, M., \& Ellison, C. G. (2000). Rethinking social reactions to crime: Personal and altruistic fear in family households. American Journal of Sociology, 106(3), 551-578.

Weinberg, J. D., Freese, J., \& McElhattan, D. (2014). Comparing data characteristics and results of an online factorial survey between a population-based and a crowdsource-recruited sample. Sociological Science, 1, 292-310.

Wetsman, N. (2020, March 10). Fearful reactions to the new coronavirus can put lives at risk. The Verge. Retrieved from https://www.theverge.com/2020/3/10/21172988/coronavirus-fear-reactions-virusebola-cdc-covid19-panic-precautions

Wheaton, B., \& Montazer, S. (2010). Stressors, stress, and distress. A handbook for the study of mental health: Social contexts, theories, and systems, 171-199.

Wheaton, B., Young, M., Montazer, S., \& Stuart-Lahman, K. (2013). Social stress in the twenty-first century. In C. S. Aneshensel, J. C. Phelan, \& A. Bierman (Eds.), Handbook of the sociology of mental health (pp. 299-323). Dordrecht, Netherlands: Springer.

Wolsko, C., Ariceaga, H., \& Seiden, J. (2016). Red, white, and blue enough to be green: Effects of moral framing on climate change attitudes and conservation behaviors. Journal of Experimental Social Psychology, 65, 7-19.

Wyant, B. R. (2008). Multilevel impacts of perceived incivilities and perceptions of crime risk on fear of crime: Isolating endogenous impacts. Journal of Research in Crime and Delinquency, 45(1), 3964.

Yang, C., Dillard, J. P., \& Li, R. (2018). Understanding fear of Zika: Personal, interpersonal, and media influences. Risk Analysis, 38(12), 2535-2545. 
Table 1. Sample Descriptives $(\mathrm{N}=990)$

\begin{tabular}{|c|c|c|c|c|c|}
\hline \multirow[b]{2}{*}{ Variable } & \multirow[b]{2}{*}{$\begin{array}{c}\text { Percent/ } \\
\text { Mean (SD) }\end{array}$} & \multirow[b]{2}{*}{ Range } & \multicolumn{3}{|c|}{ Correlations with Dependent Variables } \\
\hline & & & $\begin{array}{c}\text { Personal } \\
\text { Fear }\end{array}$ & $\begin{array}{l}\text { Altruistic } \\
\text { Fear }\end{array}$ & $\begin{array}{l}\text { Mental } \\
\text { Health } \\
\text { Harm }\end{array}$ \\
\hline \multicolumn{6}{|l|}{ Dependent Variables } \\
\hline Personal Fear & $2.92(.79)$ & $1-4$ & -- & $.619 * * *$ & $.384 * * *$ \\
\hline Altruistic Fear & $3.45(.95)$ & $1-5$ & $.619 * * *$ & -- & $.270 * * *$ \\
\hline Mental Health Harm (\%) & 57.58 & $0-1$ & $.384 * * *$ & $.270 * * *$ & -- \\
\hline \multicolumn{6}{|l|}{ Independent Variables } \\
\hline Female $(\%)$ & 40.6 & $0-1$ & $.085 * *$ & $.122 * * *$ & $.090 * *$ \\
\hline Age & $38.37(11.43)$ & $19-79$ & -.006 & $.082 * *$ & $-.088 * *$ \\
\hline White $(\%)$ & 68.8 & $0-1$ & $-.130 * * *$ & -.039 & -.040 \\
\hline Perceived Risk/Personal & $2.81(1.79)$ & $1-7$ & $.349 * * *$ & $.214 * * *$ & $.222 * * *$ \\
\hline Perceived Risk/Others & $4.00(1.31)$ & $1-7$ & $.350 * * *$ & $.277 * * *$ & $.191 * * *$ \\
\hline Republican $(\%)$ & 28.7 & $0-1$ & .002 & -.040 & .002 \\
\hline Conservative & $2.69(1.22)$ & $1-5$ & $-.088 * *$ & $-.070^{*}$ & -.061 \\
\hline Libertarian & $0.34(.38)$ & $0-1$ & $-.259 * * *$ & $-.237 * * *$ & $-.158 * * *$ \\
\hline Faith in Trump & $2.47(1.40)$ & $1-5$ & .042 & -.059 & -.003 \\
\hline Binding Foundations & $3.17(.83)$ & $1-5$ & $.231 * * *$ & $.207 * * *$ & $.121 * * *$ \\
\hline Individualizing Foundations & $3.99(.62)$ & $1-5$ & $.310 * * *$ & $.424 * * *$ & $.107 * *$ \\
\hline News awareness & $3.56(.59)$ & $1-4$ & $.250 * * *$ & $.282 * * *$ & $.198 * * *$ \\
\hline \multicolumn{6}{|l|}{ Control Variables } \\
\hline Education & $4.47(1.26)$ & $1-7$ & $.072 *$ & .029 & $.122 * * *$ \\
\hline Married (\%) & 45.4 & $0-1$ & $.107 * *$ & $.116^{* * *}$ & $.084 * *$ \\
\hline Income & $4.31(1.51)$ & $1-7$ & -.048 & -.010 & -.009 \\
\hline Religious (\%) & 59.0 & $0-1$ & $.118 * * *$ & $.144 * * *$ & $.070^{*}$ \\
\hline South $(\%)$ & 35.9 & $0-1$ & .026 & .050 & -.023 \\
\hline Low Self Control & $2.53(.96)$ & $1-5$ & $.189 * * *$ & -.015 & $.214 * * *$ \\
\hline Friends/Family Infected (\%) & 18.18 & $0-1$ & $.087 * *$ & .044 & $.193 * * *$ \\
\hline Personally Infected (\%) & 11.52 & $0-1$ &. $.066^{*}$ & .003 & $.226 * * *$ \\
\hline
\end{tabular}


Table 2. Responses to Personal Fear and Altruistic Fear Items $(\mathrm{N}=990)$

\section{Personal Fear}

Thinking about the coronavirus, how worried are you about each of the following?

1. Being exposed to the virus

2. Having to quarantine after exposure

3. Becoming sick from the virus

4. Becoming seriously ill from the virus

5. Having long-term health problems due to the virus

6. Dying from the virus

\begin{tabular}{ccccc|c} 
& & & & & \\
& $\begin{array}{c}\text { Not worried } \\
\text { at all }\end{array}$ & $\begin{array}{c}\text { Not too } \\
\text { worried }\end{array}$ & $\begin{array}{c}\text { Somewhat } \\
\text { worried }\end{array}$ & $\begin{array}{c}\text { Very } \\
\text { worried }\end{array}$ & $\begin{array}{c}\text { Total } \\
\text { Worried }\end{array}$ \\
\cline { 2 - 6 } & 5.3 & 17.0 & 41.5 & 36.3 & 77.8 \\
& 15.7 & 31.8 & 32.6 & 19.9 & 52.5 \\
& 5.7 & 18.3 & 39.0 & 37.1 & 76.1 \\
& 7.9 & 20.1 & 30.9 & 14.1 & 72.0 \\
& 11.0 & 22.3 & 28.8 & 37.9 & 66.7 \\
& 13.6 & 25.4 & 29.9 & 33.1 & 61.0 \\
\hline & & & & & \\
Very & & & & & \\
rarely & Rarely & Sometimes & Often & Very & Total \\
\hline 4.5 & 9.2 & 24.1 & 26.4 & 35.8 & Often \\
7.6 & 15.5 & 31.5 & 27.1 & 18.4 & 45.5 \\
5.2 & 8.5 & 23.7 & 29.0 & 33.6 & 62.6 \\
13.1 & 21.2 & 31.1 & 19.5 & 15.1 & 34.5 \\
6.7 & 10.9 & 23.4 & 29.0 & 30.0 & 59.0 \\
6.3 & 13.8 & 30.9 & 30.1 & 18.9 & 49.0 \\
9.9 & 15.8 & 34.8 & 24.3 & 15.2 & 39.5 \\
\hline
\end{tabular}

\section{Altruistic Fear}

How often or rarely do you WORRY about the coronavirus making the following people SICK?

1. Your family members

2. Your friends

3. Elderly people you know

4. Your neighbors

5. Doctors and nurses

6. People across America

7. People in other countries

Note: Some percentages may not equal to $100 \%$ due to rounding 
Table 3. OLS Regression Models for Personal Fear and Altruistic Fear ( $=990)$

\begin{tabular}{|c|c|c|c|c|c|c|c|c|c|c|c|c|}
\hline & \multicolumn{6}{|c|}{ Personal Fear } & \multicolumn{6}{|c|}{ Altruistic Fear } \\
\hline & \multicolumn{3}{|c|}{ Model 1} & \multicolumn{3}{|c|}{ Model 2} & \multicolumn{3}{|c|}{ Model 3} & \multicolumn{3}{|c|}{ Model 4} \\
\hline & $b$ & $S E$ & $\beta$ & $b$ & $S E$ & $\beta$ & $b$ & $S E$ & $\beta$ & $b$ & $S E$ & $\beta$ \\
\hline \multicolumn{13}{|l|}{ Vulnerability Factors } \\
\hline Female & $.091 *$ & .046 & .057 & .059 & .044 & .037 & .076 & .054 & .039 & .044 & .053 & .023 \\
\hline Age & .004 & .002 & .058 & .001 & .002 & .009 & $.005 *$ & .003 & .064 & .006 & .002 & .074 \\
\hline White & $-.148 * *$ & .050 & -.087 & $-.120 *$ & .048 & -.071 & -.058 & .059 & -.028 & -.014 & .058 & -.007 \\
\hline Perceived Risk $^{\mathrm{a}}$ & -- & -- & -- & $.117 * * *$ & .013 & .266 & -- & -- & -- & $.144 * * *$ & .021 & .198 \\
\hline \multicolumn{13}{|l|}{ Political Factors } \\
\hline Republican & .074 & .066 & .043 & .038 & .064 & .022 & .050 & .078 & .024 & .065 & .076 & .031 \\
\hline Conservative & -.028 & .025 & -.043 & -.012 & .024 & -.019 & .023 & .029 & .029 & .033 & .029 & .043 \\
\hline Libertarian & $-.476 * * *$ & .068 & -.230 & $-.417 * * *$ & .066 & -.201 & $-.459 * * *$ & .081 & -.183 & $-.415 * * *$ & .079 & -.165 \\
\hline Faith in Trump & .006 & .026 & .010 & .044 & .025 & .008 & $-.078 *$ & .030 & -.116 & $-.080 * *$ & .030 & -.118 \\
\hline Binding Foundations & $.130 * * *$ & .037 & .138 & $.122 * *$ & .036 & .130 & $.219 * * *$ & .044 & .191 & $.191 * * *$ & .043 & .167 \\
\hline $\begin{array}{l}\text { Individualizing } \\
\text { Foundations }\end{array}$ & $.243 * * *$ & .040 & .194 & $.248 * * *$ & .038 & .197 & $.443 * * *$ & .047 & .219 & $.436 * * *$ & .046 & .286 \\
\hline \multicolumn{13}{|l|}{ News Awareness } \\
\hline News awareness & $.253 * * *$ & .038 & .190 & $.231 * * *$ & .037 & .174 & $.304 * * *$ & .045 & .189 & $.276 * * *$ & .045 & .172 \\
\hline \multicolumn{13}{|l|}{ Control Variables } \\
\hline Education & -.009 & .020 & -.015 & -.008 & .019 & -.012 & -.023 & .023 & -.030 & -.017 & .023 & -.022 \\
\hline Married & .078 & .050 & .050 & .051 & .049 & .032 & $.121 *$ & .059 & .063 & .110 & .058 & .057 \\
\hline Income & $-.038 *$ & .016 & -.073 & -.025 & .016 & -.048 & -.024 & .019 & -.039 & -.018 & .019 & -.029 \\
\hline Religious & .013 & .053 & .008 & -.043 & .052 & -.027 & $.129 *$ & .063 & .067 & .068 & .062 & .035 \\
\hline South & -.014 & .046 & -.009 & -.033 & .045 & -.020 & .032 & .055 & .016 & .017 & .054 & .008 \\
\hline Low Self Control & $.129 * * *$ & .030 & .159 & $.088 * *$ & .030 & .108 & -.043 & .036 & -.043 & $-.070 *$ & .035 & -.071 \\
\hline Friends/Family Infected & -.002 & .069 & -.001 & -.048 & .067 & -.024 & .051 & .082 & .021 & .047 & .080 & .019 \\
\hline Personally Infected & -.074 & .086 & -.030 & -.152 & .083 & -.062 & .016 & .101 & .005 & -.017 & .099 & -.006 \\
\hline Adjusted R Squared & & .242 & & & 296 & & & .276 & & & 09 & \\
\hline
\end{tabular}

Note: $* \mathrm{p}<.05, * * \mathrm{p}<.01, * * * \mathrm{p}<.001{ }^{\mathrm{a}}$ The regression of personal fear includes perceived personal risk; the regression of altruistic fear includes perceived risk for others. 
Table 4. Logistic Regression Models for Mental Health Harm ( $=990)$

\begin{tabular}{|c|c|c|c|c|c|c|}
\hline & \multicolumn{6}{|c|}{ Mental Health Harm } \\
\hline & \multicolumn{3}{|c|}{ Model 1} & \multicolumn{3}{|c|}{ Model 2} \\
\hline & $b$ & $S E$ & OR & $b$ & $S E$ & $O R$ \\
\hline \multicolumn{7}{|l|}{ Fear of COVID-19 } \\
\hline Personal Fear & -- & -- & -- & $.872 * * *$ & .135 & 2.391 \\
\hline Altruistic Fear & -- & -- & -- & .165 & .112 & 1.179 \\
\hline \multicolumn{7}{|l|}{ Vulnerability Factors } \\
\hline Female & $.432 * *$ & .151 & 1.541 & $.426 * *$ & .158 & 1.531 \\
\hline Age & -.013 & .007 & .987 & $-.015 *$ & .007 & .985 \\
\hline White & .287 & .166 & 1.332 & $.437 *$ & .173 & 1.548 \\
\hline Perceived Risk & $.173 * * *$ & .047 & 1.189 & .054 & .050 & 1.056 \\
\hline \multicolumn{7}{|l|}{ Political Factors } \\
\hline Republican & .175 & .224 & 1.191 & .148 & .232 & 1.160 \\
\hline Conservative & .053 & .087 & 1.054 & .066 & .090 & 1.068 \\
\hline Libertarian & $-.536 *$ & .219 & .585 & -.125 & .237 & .883 \\
\hline Faith in Trump & $-.244 * *$ & .084 & .783 & $-.275 * *$ & .088 & .759 \\
\hline Binding Foundations & $.245^{*}$ & .119 & 1.278 & .120 & .128 & 1.128 \\
\hline Individualizing & .169 & .131 & 1.184 & -.118 & .145 & .888 \\
\hline Foundations & & & & & & \\
\hline \multicolumn{7}{|l|}{ News Awareness } \\
\hline News awareness & $.683 * * *$ & .128 & 1.979 & $.454 * *$ & .137 & 1.575 \\
\hline \multicolumn{7}{|l|}{ Control Variables } \\
\hline Education & .083 & .064 & 1.086 & .099 & .067 & 1.104 \\
\hline Married & .050 & .164 & 1.051 & -.007 & .171 & .993 \\
\hline Income & -.051 & .052 & .950 & -.027 & .054 & .973 \\
\hline Religious & -.299 & .172 & .742 & -.298 & .180 & .743 \\
\hline South & -.121 & .152 & .886 & -.100 & .159 & .905 \\
\hline Low Self Control & $.370 * * *$ & .101 & 1.448 & $.334 * *$ & .108 & 1.396 \\
\hline Friends/Family & .292 & .235 & 1.339 & .358 & .243 & 1.431 \\
\hline Infected & & & & & & \\
\hline Personally Infected & $1.421 * * *$ & .360 & 4.410 & $1.621 * * *$ & .371 & 5.056 \\
\hline Cox \& Snell R Square & & .179 & & & .238 & \\
\hline
\end{tabular}

Note: $* \mathrm{p}<.05, * * \mathrm{p}<.01, * * * \mathrm{p}<.001$ 


\section{Appendix: Survey Items}

Variable Measure

Libertarianism

Which of these statements comes CLOSEST to your view?

a. The main reason government has become bigger over the years is because it has gotten involved in things that people should do for themselves.

b. Government has become bigger because the problems we face have become bigger.

Which of these statements comes CLOSEST to your view?

a. We need the government to handle today's complex economic problems.

b. The free market can handle these problems without government being involved.

Which of these statements comes CLOSEST to your view?

a. There are more things that the government should be doing.

b. The less government, the better.

\section{Faith in Trump}

How much you agree or disagree with each of the following:

Response options: Strongly disagree, Disagree, Neither Agree nor Disagree, Agree, Strongly

Agree.

1. I believe that President Trump will make America great again.

2. President Trump is $100 \%$ correct that we need a wall to make sure that gang members, criminals, and rapists do not come into the U.S.

3. President Trump is the only politician who really cares about the common man.

4. President Trump knows how to protect America against threats from around the world.

5. I love President Trump's style because he is strong and tells it like it is.

\section{Binding Foundations}

How much you agree or disagree with each of the following:

Response options: Strongly disagree, Disagree, Neither Agree nor Disagree, Agree, Strongly

Agree.

Purity/Sanctity $(\alpha=.924)$

1. People should not do things that are disgusting, even if no one is harmed.

2. Some acts are wrong simply because they are disgusting.

3. I would call some acts wrong on the grounds that they are unnatural.

4. Some acts are wrong simply because they violate the standards of purity and decency. Authority/Respect $(\alpha=.859)$

1. Respect for authority is something all children need to learn.

2. When the government makes laws, those laws should always respect the traditions and heritage of the country.

3. People should never curse the founders or early heroes of their country.

4. People should never disrespect their bosses, teachers, or professors. 
Ingroup/Loyalty $(\alpha=.721)$

1. People should always put their group's interests above their own personal interests.

2. Loyalty to one's group is more important than one's individual concerns.

3. The government should strive to improve the well-being of people in our nation, even if it sometimes happens at the expense of people in other nations.

4. I would never turn a family member in for committing a crime.

\section{Individualizing Foundations}

How much you agree or disagree with each of the following:

Response options: Strongly disagree, Disagree, Neither Agree nor Disagree, Agree, Strongly Agree.

Harm/Care $(\alpha=.639)$

1. If I saw a mother slapping her child, I would be outraged.

2. It can never be right to kill a human being.

3. Compassion for those who are suffering is the most crucial virtue.

4. The government must first and foremost protect all people form harm. Fairness/Reciprocity $(\alpha=.775)$

1. If a friend wanted to cut in with me on a long line, I would feel uncomfortable because it wouldn't be fair to those behind me.

2. Justice, fairness, and equality are the most important requirements for a society.

3. When the government makes laws, the number one principal should be ensuring that everyone is treated fairly.

4. People should always treat others fairly and equally.

\section{Low Self-Control}

Thinking about yourself, how much do you agree or disagree with each of the following statements?

Response options: Strongly disagree, Disagree, Neither Agree nor Disagree, Agree, Strongly Agree.

1. I often act on the spur of the moment without stopping to think.

2. I often do whatever brings me pleasure here and now, even at the cost of some distant goal.

3. I frequently try to avoid projects that I know will be difficult.

4. I try to look out for myself first, even if it means making things difficult for other people.

5. I lose my temper pretty easily.

6. When I'm really angry, other people better stay away from me. 